\title{
Pemulihan Kehidupan Desa dan UU No. 22 Tahun 19991
}

\author{
R. Yando Zakaria
}

Act No. 5/1979 has caused a dualism in district institutions, autonomous region as "a longer hand" of the higher level of district and there is no participation of local institutions. Act No. 22/1999 explicitly does not repair negative impacts of the Act no 5/1979. The Villages (Desa) has treated as administrative union not as social, politic, and cultural union.

\section{Pengantar}

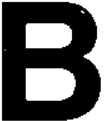

irokratisasi desa dalam sistem Pemerintahan Nasional di Republik Indonesia, melalui pemberlakukan Undang-undang Nomor 5 Tahun 1979 tentang Pemerintahan di Desa (Lembaran Negara Tahun 1979 Nomor 56, Tambahan Lembaran Negara Nomor 3153), selanjutnya disingkat UUPD No. 5/1979, telah menimbulkan dampak negatif yang tidak kecil. ${ }^{2}$ Dalam strategi birokratisasi desa itu, meski 'otonomi desa' juga disinggung-singgung, setidaknya Pasal 18 UUD 1945 juga menjadi konsiderans UUPD No. 5/1979, desa tidak hanya dirubah statusnya, yakni dari 'masyarakat hukum' menjadi 'sekumpulan orang yang tinggal bersama ...', melainkan di dalamnya juga dicangkokkan sebuah institusi baru, yaitu apa yang disebut sebagai Pemerintahan Desa.

Bersamaan dengan itu governance system (sistem pengelolan hidup bersama, pen.) yang ada dalam desa, di mana di dalamnya tercakup government system (sistem pemerintahan), digantikan oleh suatu sistem Pemerintahan Desa yang baru, yang sama sekali berbeda dan

'Disempurnakan dari makalah yang dipersiapkan bagi lokakarya-lokakarya untuk 'Penguatan Dewan Perwakilan Rakyat Daerah dan Kelompok-kelompok Masyarakat Sipil Lainnya dalam Menyongsong Otonomi Daerah', yang diselenggarakan oleh Badan Pelaksana Konsorsium Pembaruan Agraria (KPA) tahun 2000/2002, bekerjasama dengan The Ford Foundation dan BSP Kemala.

'Kata 'desa' dalam kalimat ini dengan sengaja dicetak miring. Hal ini diperlukan untuk membedakan desa sebagaimana yang dimaksudkan oleh UUPD No. 5/1979 (dalam dokumen ini dicetak biasa) dengan desa (dengan cetak miring) sebagai suatu organisasi sosial sebagaimana yang dipahami dan/ 
karenanya asing bagi warga Desa. Padahal, sejatinya, ada perbedaan 'rasa keadilan' yang amat besar antara desa sebagai suatu 'persekutuan sosial' dengän desa sebagai suatu 'satuan administrasi pemerintahan'. Ada 'rasa keadilan' yang hidup dalam desa yang tidak tertampung dalam desa sebagai 'satuan administratif pemerintahan' itu. Demikian pula, ada aturan-aturan yang ada dalam ketentuan administratif pemerintahan desa itu yang tidak sesuai dengan 'rasa keadilan' masyarakat desa yang umum berlaku. Desa yang semula hidup atas dasar sentimen paguyuban, misalnya, diubah menjadi suatu institusi yang katanya 'rasional'. Dengan pemberlakuan UU No. 5/1979 maka desa, atau yang disebut lain di wilayah kebudayaan lainnya, dipecah dan atau digabung satu sama lainnya, untuk menjadi sebuah 'desa gaya baru'. ${ }^{3}$

Akibatnya, seperti telah dikatakan tadi, proses yang menggunakan strategi transplantasi itu, meminjam prespektif Soetandjo Wignjosoebroto, ${ }^{4}$ telah menimbulkan dampak negatif yang tidak kecil. Termasuk menghancurkan energi sosial kreatif ${ }^{5}$ yang sejatinya diperlukan sebagai modal dasar bagi menjadinya Negara (Bangsa?)ini. ${ }^{6}$ Sejauh ini, dugaan saya, masalah modernisasi desa - jika dapat dikatakan begitutelah dan akan menjadi salah satu titik tolak bagi berkembangnya sentimen antiNegara (sekaligus juga Bangsa) dan mendorong munculnya kesadaran politik di tingkat suku-bangsa (ethno-nationalism) yang mengancam integrasi Negara yang teris meningkat intensitasnya dalam beberapa tahun belakangan ini. Di masa-masa yang akan datang, jika persoalan ini tidak dapat dicarikan solusinya secara tepat dan cepat, bukan tidak mungkin sentimen antiNegara dan ethno-nationalism itu akan makin membesar lagi.? atau dikonsepsikan oleh warga persekutuan sosial yang bersangkutan. Penyebutan desa dalam dokumen ini dapat juga berarti dan/ atau dipertukarkan dengan nagari (di Minangkabau), marga (di Palembang), dan lain sebagainya.

${ }^{3}$ Rangkuman pandangan berbagai pihak, termasuk penulis sendiri, periksalah R. Yando Zakaria, Abih Tandeh, Masyarakat Desa di Bawah Orde Baru. Jakarta: Lembaga Studi dan Advokasi Masyarakat (ELSAM), 2000.

${ }^{4}$ Soetandjo Wignjosoebroto, "Komunitas Lokal versus Negara Bangsa: Perbedaan Persepsi dan Konsepsi Tentang Makna Lingkungan". Makalah yang dipresentasikan dalam diskusi bertemakan "Hubungan Negara - Masyarakat dalam Pengelolaan Lingkungan" yang diselenggarakan oleh Yayasan Lembaga Bantuan Hukum Indonesia, Jakarta, tanggal 3 Juli 1997.

'Lihat Uphoff, Leaming From Gal Oya, Possibilities for Particippatory Development and Post Newtonian Social Science. London: Intermediate Technology Publications Ltd, 1996.

'Baru-baru ini, dalam sebuah seminar Nasional yang diselenggarakan oleh Lembaga IImu Pengetahuan Indonesia (LIPI), Prof. Dr. Taufik Abdullah, sejarawan yang tengah menjabat ketua lembaga yang bersangkutan, secara meyakinkan mengatakan bahwa pemberlakuan UU No. 5/1979, yang telah menimbulkan dampak negatif yang tidak terhingga itu, merupakan (salah satu, pen.) kesalahan sejarah Nasional terbesar yang pernah terjadi selama ini.

'Zakaria, op.cit. Tentu saja saya tidak akan menangisi jika disintegrasi itu benarbenar terwujud (lihat pandangan saya tentang hal ini pada bagian Penutup). Hanya saja, jika itu terjadi dalam situasi di mana 'negara adalah sesuatu yang sakral', disintegrasi itu tentunya akan disertai chaos yang menuntut korban nyawa, rasa peri kemanusian, dan harta-benda. Hal yang demikian itulah yang sama sekali tidak saya inginkan. 
Karenanya, menjadi tepat sekali jika masalah ini menjadi salah satu agenda reformasi yang tengah bergulir sejak tumbangnya rezim Orde Baru di pertengahan tahun 1998 lalu itu. Sesuai dengan semangat Pasal 18 UUD 1945, berbeda dengan UU No. 5/1979, melalui pemberlakuan UU No. 22/1999 tentang Pemerintahan Daerah, desa dalam sistem administrasi Pemerintahan Nasional telah dikembalikan 'statusnya' sebagai mana mestinya. Pada Bab 1, Ketentuan Umum, Pasal 1, Butir o. antara lain dinyatakan bahwa "Desa atau yang disebut dengan nama lain, selanjutnya disebut desa, adalah kesatuan masyarakat hukum yang memiliki kewenangan untuk mengatur dan mengurus kepentingan masyarakat setempat berdasarkan asal-usul dan adatistiadat setempat yang diakui dalam sistem Pemerintahan Nasional ... " (cetak miring oleh penulis, pen.). Sebelumnya, dalam UU No. 5/1979, desa didefenisikan sebagai "suatu' wilayah yang ditempati oleh sejumlah penduduk sebagai kesatuan masyarakat termasuk di dalamnya kesatuan masyarakat hukum yang mempunyai organisasi pemerintahan terendah langsung di bawah Camat .... " (Pasal 1 butir a) (cetak miring ditambahkan, pen.).

Yang menarik, dalam bagian Menimbang butir e. UU No. 22/1999 dikatakan "bahwa Undang-undang Nomor 5 Tahun 1979 tentang Pemerintahan di Desa (Lembaran Negara Tahun 1979 Nomor 56, Tambahan Lembaran Negara Nomor 3153) yang menyeragamkan nama, bentuk, susunan, dan kedudukan pemerintahan desa, tidak sesuai dengan jiwa Undang-undang Dasar 1945 dan perlunya mengakui serta menghormati hak asal-usul Daerah yang bersifat istimewa sehingga perlu diganti" (cetak miring ditambahkan, pen.). Suatu keputusan politik yang tepat dan aspiratif, meski terasa agak terlambat dan diperhalus maknanya. ${ }^{8}$ Barangkali, baru kali inilah ada sebuah undang-undang di sebuah negara yang dinyatakan oleh undang-undangnya yang lain sebagai undang-undang yang tidak sesuai dengan konstitusi negara itu. ${ }^{9}$

Lepas dari permasalahan tersebut, pertanyaan pokok kita adalah apakah ketentuan-ketentuan yang menyangkut Desa dan Pemerintahan Desa sebagaimana yang terkandung pada UU No. 22/1999 tentang Pemerintahan Daerah yang baru itu

'Menurut hemat saya, hal ini bukannya sekedar 'tidak sesuai', melainkan merupakan suatu 'pelanggaran' (lihat R. Yando Zakaria, "Penegasian Hak-Hak Masyarakat Adat Sebagai Sumber Krisis Integrasi Nasional di Masa Depan", makalah yang disampaikan pada "Widyakarya Nasional Antropologi dan Pembangunan", diselenggarakan oleh Direktorat Jenderal Kebudayaan DEPDIKBUD dan Panitia Kongres Asosiasi Antropologi Indonesia, 26 - 27 Agustus 1997, sebuah tulisan yang dipublikasikan jauh sebelum UU No. 22/1999 muncul). Lihat juga dokumentasi-dokumentasi penyelenggaraan Kongres Masyarakat Adat Nusantara yang diselenggarakan tahun 1998. Hemat saya, frasa 'tidak sesuai' membangun citra adanya 'ketidaksengajaan', meminjam kata-kata Noer Fauzi, hasil dari suatu 'sesat pikir'. Sedangkan frasa 'pelanggaran' justru akan bercitra sebaliknya (tentang hal ini periksalah Zakaria, 1997, ibid., dan 2000, op.cit., khususnya Bab III). Karenanya kejadian itu layak pula ditindaklanjuti secara hukum dan politik (lihat catatan kaki berikut).

${ }^{9} T e n t a n g$ kasus pelanggaran konstitusi ini, sebenarnya menarik juga untuk memikirkan proses-proses hukum dan politik apa yang dapat ditempuh di masa depan. Tujuannya agar Negara ini tidak begitu mudah melakukan pelanggaran-pelanggaran hak asasi manusia atas nama peraturan perundangan-undangan tertentu, sebagaimana yang terjadi pada kasus pemberlakuan UU No. 5/1979 tentang Pemerintahan Desa ini. Namun itu bukan maksud tulisan singkàt ini. 
memang telah memaknai dan memperlakukan desa sebagaimana mestinya, sehingga mampu memulihkan dampak yang telah diderita desa selama ini? Lebih jauh dapat pula kita bertanya: apakah penataan ulang hubungan antara Negara dan Komuniti tersebut, jika memang itu terjadi, telah menjamin terciptanya kondisi yang memungkinkan bagi terus berlangsungnya upaya penciptaan negara-bangsa (nation state) indonesia di masa-masa yang akan datang?

Tulisan ini bermaksud menjawab pertanyaan-pertanyaan pokok tersebut. Di samping bagian Pengantar ini, tulisan ini terbagi ke dalam tiga bagian utama. Bagian pertama dimulai dengan uraian tentang masalah dasar dari apa yang saya sebut sebagai ketegangan abadi antara Negara dan Desa (baca: komuniti). Dalam bagian ini diuraikan pula kedudukan 'susunan asii' ini dalam Negara Kesatuan Republik Indonesia menurut Pasal 18 UUD 1945 (termasuk hasil amandemen tahun 2000 lalu), berikut makna dasar desa sebagai 'persekutuan sosial'. Bagian kedua pada dasarnya berisikan uraian dan pembahasan tentang kedudukan desa dan Pemerintahan Desa menurut UU No. 22/1999 tentang Pemerintahan Daerah. Bagian ketiga, bagian akhir tulisan ini, berisikan tawaran berupa gagasan pokok tentang peraturan perundang-undangan yang dibutuhkan bagi pemulihan kehidupan di desa. Bagian ini diawali dengan uraian tentang 5 (lima) kebutuhan dasar bagi keberlangsungan dan peningkatan kesejahteraan hidup warga desa, dan dilanjutkan dengan bentuk perangkat peraturan perundang-undangan yang dibutuhkan untuk mencapainya di masa-masa yang akan datang.

\section{Negara dan Komuniti: Ketegangan yang Nyaris Abadi ${ }^{10}$}

“... Tidak ada partisipasi atau mobilisasi rakyat secara tetap, yang ada adalah bentuk partisipasi yang secara tetap melibatkan begitu banyak warganegara sehubungan dengan pelaksanaan kebijakan nasional dan bukan pembuatan kebijakan

${ }^{10} \mathrm{Bagian}$ ini dengan sengaja menggunakan kata komuniti, bukan rakyat ataupun masyarakat, untuk menghindari diri dari belitan pemaknaan yang netral dan longgar dari kedua kata yang disebut terakhir. Adapun yang dimaksud dengan komuniti dalam tulisan ini adalah menunjuk pada 'satuan hidup masyarakat setempat yang khas, dengan suatu identitas dan solidaritas yang telah terbentuk dari dalam dan berkembang dalam waktu yang lama'. Sedangkan 'komunitas' dipakai guna mengacu pada 'kelompok di dalam masyarakat yang dibentuk dari atas, sehingga identitas dan solidaritas antar penduduknya masih lemah' (Koentjaraningrat, Sejarah Teori Antropologi II, Jakarta: UI Press, 1990, hal. 135. Saya berterima kasih kepada Noer Fauzi, Ketua Badan Penguris Konsorsium Pembaruan Agraria, dalam "Pengantar Editorial" Jurnal Masyarakat Adat, No. 1, Thn. 1998. Bandung: BP Konsorsium Pembaruan Agraria, yang telah mengingatkan saya pada apa yang diusulkan Koentjaraningrat ini). Dalam buku Koentjaraningrat lainnya yang terbit lebih awal, community didefenisikannya sebagai "kesatuan hidup manusia, yang menempati suatu wilayah yang nyata, dan yang berinteraksi menurut suatu sistem adat-istiadat, serta yang terikat oleh suatu rasa identitas komuniti' (Koentjaraningrat, Pengantar IImu Antropologi. Jakarta: Aksara Baru, 1979, hal. 162. Lihat juga Koentjaraningrat, et.al., loc.cit, 1984; dan Koentjaraningrat, ibid., 1985, hal. 155). Dengan demikian, dalam pembahasan nanti, warga negara tidak hanya diacu ke dalam 
itu ...". Demikian salah satu ciri sistem pemerintahan di Indonesia, yang oleh Jackson (1978) didefenisikannya sebagai suatu sistem pemerintahan birokratis. Lebih jauh dikatakannya pula bahwa partisipasi lokal cenderung diatur lewat otoritas tradisional dan pengelompokan patron-klien dan bukan lewat kelompok yang berdasarkan pada atribut sosial yang sama, misalnya kelas. Selain itu, Mobilisasi penduduk yang efektif hanya ditujukan untuk langkahlangkah jangka pendek, seperti pemilihan umum dan demonstrasi. Keterbatasan utama pemerintah adalah ketidakmampuannya untuk memobilisasi rakyat yang berkorban demi program-program nasional tertentu dan untuk mencapai target-target yang memerlukan partisipasi yang benarbenar sukarela dari rakyat secara keseluruhan."

Dengan demikian, terdapat jurang yang memisahkan pemerintah di satu pihak dengan rakyat di pihak lain. Sehingga, sudah sejak lama para ahli memikirkan bagaimana jurang ini dapat dijembati dan dengan jalan apa rakyat dapat dibujuk untuk ikut terlibat (dalam berbagai kegiatan bemegara, termasuk program-program pembangunan, pen.)..$^{12}$ Jurang pemisah antara "sektor" pemerintah dan rakyat ini diwarnai -meminjam istilah yang digunakan Bijlmer \& Reurink, ketegangan. Sebagaimana dikonsepsikan Bijlmer \& Reurink, ketegangan ini muncul sebagai akibat adanya perbedaan-perbedaan antara apa yang disebut Bijlmer \& Reurink sebagai norma lokal di satu pihak, dan norma pemerintah di pihak lain. Norma lokal mengacu pada konsepsikonsepsi masyarakat dalam melihat berbagai hal, termasuk kebijakan pemerintah dan kebutuhan-kebutuhan hidupnya sendiri sebagaimana yang mereka lihat. Menurut pendapat rakyat setempat, lingkungan atau kampung memiliki arti konkret. Harapan .dan kepentingan mereka juga konkret. Di pihak lain, norma pemerintah juga mengacu pada hal yang sama, hanya saja sebagaimana dirumuskan sendir oleh pihak pemerintah itu. ${ }^{13}$

Dalam konteks ini Ufford menulis: "... Sebagai penwakilan dari tingkat organisasi yang lebih tinggi, kepala desa, tenaga kerja lapangan dan pegawai kantor agama setempat (dan-lembaga-lembaga lain yang terkait pada sistem organisasi pemerintahan di tingkat desa ini, pen.), menghadapi banyak tuntutan dari atasan mereka yang harus dipenuhi. "Kedudukan mereka sendiri adalah kurang lebih suatu program pemerintahan juga (cetak miring oleh penulis). Peranan resmi mereka menampilkan sikap dari penguasa pusat. Sebagai kepala desa, mereka adalah pejabat nasional yang ditempatkan di daerah. Setiap orang mengetahui tugas resmi dari pegawai administrasi dalam memelihara hukum dan ketertiban, dan mewujudkan pembangunan dalam sejumlah program dan proyek". ${ }^{14}$

kategori-kategori yang netral dan longgar itu, tetapi secara khusus diacu dalam kategori ikatan-ikatan sosial dan kultural yang khusus. Dengan cara demikian, pembicaraan tentang ketegangan antara negara dan konstituennya menjadi lebih tajam.

"Dikutip dari Joep Bijlmer \& Martin Reurink, "Kepemimpinan Lokal di Lingkungan Urban Jawa: dari Ideologi ke Realitas", dalam Philip Quarles van Ufford, ed., Kepemimpinan Lokal dan Implementasi Program. Jakarta: PT. Gramedia, 1988: 151. Melalui penelitian mereka pada komuniti-komuniti urban di Semarang dan Surabaya, Joep Bijlmer \& Martin Reurink (ibid., 1988: 168) mendukung tesis-tesis yang dikemukakan Jackson ini.

${ }^{12}$ Lihat, misalnya, Joep Bijlmer \& Martin Reurink, ibid., 1988: 168.

${ }^{13}$ Bijlmer \& Reurink, ibid., 1988, khususnya hal. 159-163.

${ }^{14}$ Ufford, ibid., hal. ix. 
UUPD No. 5/1979 memang telah mengubah total wajah desa jika dibandingkan dengan masa-masa sebelumnya, ${ }^{15}$ dan perubahan itu bukanlah suatu perubahan yang tidak direncanakan (by accident) melainkan suatu perubahan yang memang direncanakan sedemikian rupa (by design), melalui suatu perdebatan politik di antara kekuatankekuatan politik yang tidak berimbang di bawah bayang-bayang etika politik yang didominasi oleh kekuatan rezim 'orde baru' yang jauh dari semangat demokratisasi. ${ }^{16}$ Meski begitu, tentu akan terkesan naif dan tidak adil jika kita menyatakan bahwa 'kasus UUPD No. 5/1979' sebagai satusatunya peristiwa, yang terjadi begitu saja, dari ketegangan antara negara dan desa (baca: komuniti) sepanjang sejarahnya. Pengamatan Jackson sendiri telah dilakukan jauh sebelum UUPD No. 5/1979 diundangkan dan diberlakukan di seluruh negeri. Namun, mengacu pada hasil pengamatan Bijlmer \& Reurink (1988), ${ }^{17}$ Jatiman (1995), ${ }^{18}$ Zakaria (2000), ${ }^{19}$ dan Syafitri (2001), ${ }^{20}$ sekedar menyebut beberapa contoh saja, boleh jadi 'kasus UUPD No. 5/1979' adalah puncak dari, untuk sementara ini, hubungan yang cenderung negatif di antara kedua entitas sosial dan politik tersebut. Puncak ini terjadi ketika hubungan itu telah berubah corak: dari sekedar (dominan) interaksi menjadi seutuhnya (dominan) intervensi.

Sejatinya desa adalah 'negara kecil', atau apa yang dimaksud Ter Haar sebagai dops republic, karena sebagai masyarakat hukum desa memiliki semua perangkat suatu negara: teritori, warga, aturan atau hukum (rules atau laws) dan pemerintahan. Dengan ungkapan lain, pemerintahan desa memiliki alat (polisi dan pengadilan desa) dengan mekanisme (aturan/hukum) untuk menjalankan 'hak menggunakan kekerasan' (coercion) di dalam teritori atau wilayah (domain) hukumnya. Wilayah keberlakukan (domain) hukum suatu masyarakat hukum dapat berupa suatu teritori yang tetap; artinya berlaku bagi setiap orang yang berada di wilayah itu dan/atau bagi setiap warga masyarakat itu, di manapun ia berada. Pada masyarakat hukum yang relatif lanjut, artinya telah memperlakukan teritori sebagai klaim justifikasi (yang tidak boleh dimasuki oleh bukan warga komuniti dan sanksi bagi yang melanggarnya), kedua hal tersebut berlaku. Sementara, bagi masyarakat hukum yang tingkat perkembangannya masih sangat awal, yang memperlakukan teritori 'sekedar basis material' yang dapat dimiliki bersama dengan masyarakat politik lain, maka wilayah keberlakuan hukumnya bukanlah teritori, melainkan hanya warga masyarakat itu. Barangkali, bedanya yang paling signifikan dengan Negara (state) boleh jadi adalahnya tidak adanya pengakuan kedaulatan oleh negara-negara lain secara intemasional.

${ }^{15}$ Disebut total di sini untuk membedakan bentuk perubahan-perubahan yang sejatinya juga telah pernah dialami desa sepanjang sejarah hidupnya. Bedanya, perbedaan wajah setelah pemberlakukan UUPD No. 5/ 1979 ini jauh 'lebih berarti' ketimbang perubahan-perubahan pada masa-masa sebelumnya itu. Lihat Zakaria, 2000 , op.cit.

${ }^{16}$ Lebih jauh periksalah Zakaria, 2000, op.cit, khususnya Bab 2 dan Bab 3.

${ }^{17}$ Bijlmer \& Reurink, op.cit., 1988

${ }^{18}$ Sardjono Jatiman, Dari Kampung Menjadi Desa: Studi Sosiologis Perubahan Pemerintahan Desa di Kabupaten Sambas, Kalimantan Barat. Disertasi Doktoral pada Program Pascasarjana Universitas Indonesia, 1995. Tidak diterbitkan.

${ }^{19}$ Zakaria, 2000, op.cit.

${ }^{20}$ Myrna Syafitri, Desa, Institusi Lokal dan Pengelolaan Hutan: Refleksi Kebijakan dan Praktik. Jakarta: Lembaga Studi dan Advokasi Masyarakat, 2000. 
Studi Shapera (1967), ${ }^{21}$ seorang ahli antropologi, tentang sistem pemerintahan suku-suku primitif22 di Afrika Selatan menunjukkan bahwa tidak ada perbedaan yang mendasar antara 'masyarakat primitif' dengan 'masyarakat beradab' yang kita kenal saat ini. Kedua masyarakat politik itu dibentuk oleh unsur-unsur yang sama, yaitu ikatan kekerabatan dan ikatan teritorial. Dengan demikian Shapera membantah pemikir-pemikir antropologi lainnya, seperti Mclver dan bahkan Malinowski, yang menganggap seolah-olah pada 'masyarakat primitif' organisasi politiknya hanya dibentuk oleh ikatan kekerabatan semata. ${ }^{23}$ Dengan mengambil beberapa contoh, khususnya di Afrika, Shapera menunjukkan bahwa warga masyarakat dimaksud tidak hanya terikat dalam satu ikatan kekerabatan; mereka bahkan dapat berasal dari suku yang berbeda, yang diikat oleh kesamaan tempat tinggal, wilayah perburuan, dan sebagainya. ${ }^{24} \mathrm{Kalaupun}$ ada perbedaan yang hendak dikatakan, hal ini terletak pada lebih pentingnya ikatan kekerabatan pada 'masyarakat primitif' dibandingkan dengan pada 'masyarakat beradab' dan/atau 'masyarakat modern'.

Berkaitan dengan efektivitas aturan dan pemerintahan, Shapera dalam tulisan yang sama menunjukkan bahwa meskipun relatif 'minimal', namun fungsi pemerintahan pada masyarakat-masyarakat politik yang dikaji berjalan efektif: selain menjaga batas-batas teritorial dan agresi dari luar, fungsi pemerintahan yang ditemui di semua masyarakat adalah pengorganisasian dan pengarahan untuk hal-hal yang berkaitan dengan kerjasama selunuh warga masyarakat. ${ }^{25}$ Demikian pula dengan aturan dan hukum. Meskipun masyarakat-masyarakat itu tidak memiliki sistem pengadilan dan bahkan pemimpinpemimpin mereka tidak pula mampu menghukum pelanggar aturan, namun toh masyarakat itu dapat tetap hidup dalam keter- aturan. Sebagai 'pengganti' mekanisme penggunaan kekerasan (coersion) secara sah sebagai penjamin ketentraman, mereka mengembangkan 'internal cooperation and external independence' sebagai basis kehidupan bersama mereka. ${ }^{26}$

Dalam pada itu, berbagai sumber menunjukkan bahwa ketegangan antara negara dan komuniti ini terus meningkat seiring dengan berubahnya corak hubungan antara negara dan komuniti dari yang semula lebih dominan interkasi menjadi dominan intervensi.. Catatan-catatan sejarah yang tersedia secara pasti juga menunjukkan langkah pergeseran yang cenderung linier: secara pasti bergerak dari arah (dominan) interaksi menuju (dominan) intervensi ini.. ${ }^{27}$

21. Shapera, Government and Politics in Tribal Societies. New York: Schoken Books, 1967.

2Yang dimaksud dengan primitif di sini harus dibaca dalam konteks pencapaian teknologi, bukan dalam dominannya unsurunsur irasionalitas dalam benak manusia, sebagaimana dimaksud dalam teori psikologi Jungian. Lebih jauh, lihat Lucy Mair, Primitive Government: A Study of Tradisional Political System in Eastem Africa. Bloomington: Indiana University Press, 1962, hal. 10.

${ }^{23}$ Shapera, 1967, op.cit., hal. 3-5.

${ }^{24} \mathrm{Di}$ sini, keberlakuan konsep teritorial mungkin hanya sebagai 'basis material' atau sumber ekonomi, dengan implikasi wilayah dimaksud dapat saja dimasuki oleh warga komuniti lainny. Jadi semacam common-pool resources. Pada komuniti yang lain, yang mungkin di acu para ahli di atas, konsep teritorial telah diberlakukann lebih jauh, yaitu sebagai wilayah kedaulatan komuniti, yang bermakna hukum. Konsekuensinya, warga komuniti lain yang memasuki wilayah inii akan mendapat sakksi, yang umumnya berat.

${ }^{25}$ Shapera, 1967, op.cit., hal. 217.

${ }^{26}$ Shapera, 1967, op.cit., hal. 218.

${ }^{27}$ Sebagai ilustrasi, cobalah tengok urutan-urutan peristiwa berikut ini: (a) kisah 
Di Nusantara, sepanjang sejarahnya, desa telah mengalami interaksi dengan, dan/atau intervensi oleh, berbagai kebijaksanaan negara. Setidaknya hal ini telah dimulai sejak masa pemerintahan 'kerajaankerajaan pribumi' (masa prakolonial), negara kolonial (dari VOC hingga pemerintahan Hindia Belanda), hingga setelah munculnya Negara Kesatuan Republik Indonesia sendiri. Di sebut interkasi jika perhubungan keduanya relatif sejajar, atau paling kurang, posisi tawar desa relatif seimbang. Dalam situasi yang demikian negara tidak dapat memaksakan agendanya tanpa menimbulkan risiko yang fatal bagi eksistensi negara itu sendiri. Karena itu, perhubungan antara keduanya dapat dikatakan berangkat dari kebutuhan para pihak, bukan hanya salah satu di antaranya. Sebaliknya, dalam corak hubungan intervensi, selain posisi para pihak tidak sejajar/tidak seimbang karena posisi tawar salah satu pihak lebih rendah, perhubungan terjadi karena kemauan, bahkan pemaksaan, pihak yang kuat. Argumentasi bahwa "karena kebutuhan pihak (yang lebih) lemah, yang belum mampu mendefinisikan kebutuhannya sendiri' harus ditafsirkan sebagai argumentasi hegemonik pihak yang kuat, untuk menjustifikasi campur tangannya.

\section{Otonomi Desa Menurut Pasal 18 UUD 1945}

Jika begitu keadaannya masih adakah ruang untuk membalikkan bandul kembali menjadi dominan interaksi? Sebelum menjawab pertanyaan ini baiklah kita periksa bagaimana konstitusi kita mengatur keberadan komuniti (baca: desa) ini. Pada Undang-undang Dasar Negara Republik Indonesia Tahun 1945 (Berita Republik Indonesia, II, 7, hal. 45 - 48; Penjelasan hal. 51 - 56), khususnya Bab VI, yang berjudul Pemerintahan Daerah, terdapat Pasal 18 yang berbunyi "Pembagian daerah Indonesia atas daerah besar dan kecil dengan bentuk susunan pemerintahannya ditetapkan dengan Undang-undang, dengan memandang dan mengingat dasar permusyawaratan dalam sistem Pemerintahan Negara, dan hak-hak asal-usul dalam daerah-daerah yang bersifat istimewa" ${ }^{28}$

hub. negara - komuniti pada masa Kerajaan Mataram di Jawa (Soemarsaid Moertono, Negara dan Usaha Bina-Negara di Jawa Masa Lampau, Studi Tentang Masa Matara II, Abad XVI - XIX. Jakarta: Yayasan Obor Indonesia, 1985); kisah hub. negara - komuniti pada masa Kerajaan Todo-Pongkor di Manggarai (Dami N. Toda, Manggarai Mencari Pencerahan Historiografi. Ende: Penerbit Nusa Indah, 1999); desa dalam sistem pemerintahan Raffles dan desa dalam sistem pemerintahan Kolonial Belanda pasca Raffles di Jawa (antara lain, periksalah Frans Husken, Masyarakat Desa dalam Perubahan Zaman, Sejarah Deferensiasi Sosial di Jawa 1830 1980); nagari di Minangkabau, termasuk diakuimya pengadilan adat (misalnya dalam Kebeet von Benda-Beckmann, Goyahnya Tangga Menuju Mufakat, Jakarta: PT. Gramedia Widiasarana Indonesia dan Perwakilan Koninklijk Instituut voor Taal-Landen Volkenkunde, 2000; dan Franz von BendaBeckmann, Properti dan Kesinambungan Sosial. Jakarta: PT. Gramedia Widiasarana Indonesia dan Perwakilan Koninklijk Instituut voor Taal-Land- en Volkenkunde, 2000); Pemberlakuan IGO \& IGOB oleh Kolonial Belanda dan desa dalam berbagai UU RI sebelum UU No. 5/1979 (misalnya lihat Zakaria, 2000, op.cit). Ternyata ini bukan fenomena khas Indonesia, tetapi juga di negara lain, sepertti di Cina (I. Wibowo, Negara dan Masyarakat, Berkaca dari Pengalaman Republik Rakyat Cina. Jakarta: Gramedia Pustaka Utama dan Pusat Studi Cina, 2000.

${ }^{28}$ Kutipan-kutipan tentang UndangUndang Dasar 1945 bersumber dari doku- 
Pada Penjelasan Undang-Undang Dasar Negara Republik Indonesia Tahun 1945, khususnya dalam bagian Penjelasan Sepasal Demi Sepasal, untuk Bab VI, Pasal 18 ini diberikan catatan sebagai berikut:

“l. Oleh karena Negara Indonesia itu suatu "eenheistaat", maka Indonesia tak akan mempunyai daerah di dalam lingkungannya yang bersifat "Staat" juga.

Daerah Indonesia akan dibagi dalam daerah propinsi, dan daerah propinsi akan dibagi pula dalam daerah yang lebih kecil.

Daerah-daerah yang bersifat outonoom (streek dan locale rechtsgemeenschappen) atau bersifat daerah administrasi belaka, semuanya menurut aturan yang akan ditetapkan dengan undang-undang.

Di daerah-daerah yang bersifat outonoom akan diadakan badan perwakilan daerah, oleh karena di daerah pun pemerintahan akan bersendi atas dasar permusyawaratan.

II. Dalam territoir Negara Indonesia terdapat lebih kurang $250^{\circ}$ Zelfbesturende landschappen" dan "Volksgemeenschappen", seperti desa di Jawa dan Bali, negeri di Minangkabau, dusun dan marga di Palembang dan sebagainya. Daerah-daerah itu mempunyai susunan asli dan oleh karenanya dapat dianggap sebagai daerah yang bersifat istimewa.

Negara Republik Indonesia menghormati kedudukan daerah-daerah istimewa tersebut dan segala peraturan negara yang mengenai daerah itu akan mengingati hakhak asal-usul daerah tersebut".

Jika dilihat secara mendalam makna pengaturan sebagaimana tercantum dalam Pasal 18 UUD 45 berikut Penjelasannya itu maka dapat dikatakan bahwa esensi dari Pasal 18 UUD 1945 adalah adanya pengakuan Negara terhadap apa yang disebut dengan 'otonomi desa' dewasa ini. Lebih dari itu, dengan menyebutkan desa sebagai susunan asli yang memiliki hak asal-usul, maka menurut UUD 45, hanya desa yang dipastikan memiliki otonomi. Sedangkan 'daerah-daerah besar dan kecil lainnya', semacam propinsi, kabupaten, atau kecamatan yang dikenal dalam sistem Pemerintahan Nasional sekarang ini, dapat saja bersifat otonom atau administratif belaka. Apakah masing-masing 'daerah besar dan kecil' itu diberi status otonom atau administratif tergantung 'kebutuhan', perimbangan kekuatan politik Pusat dan Daerah, sebagaimana dituangkan di dalam Undang-undang. ${ }^{29}$

Selain itu, dengan menyebut desa sebagai susunan asli maka desa adalah 'persekutuan sosial, ekonomi, politik, dan budaya' yang berbeda hakekatnya dengan sebuah 'persekutuan administratif' sebagaimana yang dimaksudkan dengan 'peme-

men/buku yang berjudul Tiga UndangUndang Dasar: UUD RI 1945, Konstitusi RIS, UUD Sementara $R I$, yang dihimpun dan diterbitkan oleh Penerbit Ghalia Indonesia, Cetakan keenam, 1995.

${ }^{29}$ Telah terdapat sekurang-kurangnya 7 peraturan perundangan yang mengatur masalah ini. Pada masing-masing peraturan perundangan itu terdapat kecenderungan yang berbeda satu sama lainnya. Tentang hal ini periksalah Bhenyamin Hoessen, Berbagai Faktor Yang Mempengaruhi Besarnya Otonomi Daerah Tingkat II, Suatu Kajian Desentralisasi dan Otonomi Daerah Dari Segi IImu Administrasi Negara. Disertasi untuk Gelar Doktor pada Program Pascasarjana Universitas Indonesia, 1993 dan Desentralisasi dan Otonomi Daerah di Negara Kesatuan Republik Indonesia", Naskah Pidato Pengukuhan Guru Besar dalam Ilmu Administrasi Negara pada Fakultas IImu Sosial dan IImu Politik Universitas Indonesia, 1995. Lihat juga Zakaria, 2000, op.cit., khususnya pada hal. $33-87$. 
rintahan desa' dalam berbagai peraturanperundangan yang ada. Karenanya, sebagai susunan asli, kerapkali desa mewujudkan diri sebagai apa yang disebut Ter Haar sebagai dorps republik atau 'negara kecil', sebagai lawan kata 'negara besar' yang mengacu pada suatu tatanan modern state.

Berkaitan dengan adanya pengakuan atas otonomi desa ini, dalam wacana politik-hukum, dikenal adanya dua macam konsep hak berdasarkan asal usulnya. Masing-masing hak berbeda satu sama lainnya. Pertama, yaitu hak yang bersifat berian (hak berian), dan kedua adalah hak yang merupakan bawaan yang melekat pada sejarah asal-usul unit yang memiliki otonomi itu (hak bawaan) (Ndraha, 2000). Dengan menggunakan dua pembedaan ini, maka digolongkan bahwa otonomi daerah yang dibicarakan banyak orang dewasa ini adalah otonomi yang bersifat berian ini. Karena itu, wacananya bergeser dari hak menjadi wewenang (authority). Kewenangan selalu merupakan pemberian, yang selalu harus dipertanggungjawabkan. Selain itu, konsep urusan rumah tangga daerah hilang diganti dengan dengan konsep kepentingan masyarakat. Dengan demikian, otonomi daerah merupakan kewenangan pemerintahan daerah untuk mengatur kepentingan masyarakat di daerah.

Berbeda dengan hak yang bersifat berian adalah hak yang bersifat bawaan, yang telah tumbuh-berkembang dan terpelihara oleh suatu kelembagaan (institution) yang mengurus unusan rumah tangganya sendiri. Dalam UUD 1945, konsep hak yang bersifat bawaan inilah yang melekat pada "daerah yang bersifat istimewa" yang memiliki "hak-hak asal-usul". Karena itu, berbeda dengan 'pemerintah daerah', desa dengan otonomi desa, yang muncul sebagai akibat diakuinya hak asal-usul dan karenanya bersifat istimewa itu, memiliki hak bawaan.
Hak bawaan dari desa sebagai susunan asli itu setidaknya mencakup hak atas wilayah (yang kemudian disebut sebagai wilayah hak ulayat), ${ }^{30}$ sistem pengorganjsasian sosial yang ada di wilayah yang bersangkutan (sistem kepemimpinan termasuk di dalamnya), aturan-aturan dan mekanisme-mekanisme pembuatan aturan di wilayah yang bersangkutan, yang mengatur seluruh warga ('asli' atau pendatang) yang tercakup di wilayah desa yang bersangkutan.

Sejatinya inilah pangkal dari ketegangan yang nyaris abadi antara Negara di satu pihak dengan masyarakat (baca: komunitas dan/atau desa) di pihak lain. Ketegangan itu menyangkut hal bagaimana Negara merealisasikan otonomi desa yang secara politik dan hukum terakomodasi dalam peraturan-perundangan yang ada. Khususnya yang menyangkut hak atas penguasaan atas wilayah desa, aturan-aturan, dan sistem pengorganisasian hidup bersama di wilayah itu.

\section{Desa dan Pemerintahan Desa menurut UU No. 22/1999}

Desa berdasarkan undang-undang ini adalah Desa atau yang disebut dengan nama lain sebagai suatu kesatuan masyarakat hukum yang mempunyai susunan asli berdasarkan hak asal-usul yang bersifat istimewa, sebagaimana dimaksud dalam penjelasan pasal 18 Undang-undang Dasar 1945. Dalam Bab 1, Ketentuan Umum, Pasal 1, butir o. dinyatakan bahwa "Desa atau yang disebut dengan nama lain, selanjutnya disebut desa, adalah kesatuan

30Karenanya bagi saya 'hak ulayat' lebih mengacu pada pengertian 'wilayah kedaulatan' dan bukan 'hak garap bersama' (Lihat Zakaria, 2000, op.cit., khususnya pada hal 241 - 258). 
masyarakat hukum yang memiliki kewenangan untuk mengatur dan mengurus kepentingan masyarakat setempat berdasarkan asal-usul dan adat istiadat setempat yang diakui dalam sistem Pemerintahan Nasional dan berada di daerah kabupaten".

Landasan pemikiran dalam pengaturan mengenai Pemerintahan Desa adalah keanekaragaman, partisipasi, otonomi asli, demokratisasi, dan pemberdayaan masyarakat (Penjelasan, Umum, angka 9, butir 1).

Penyelenggaraan pemerintahan Desa merupakan subsistem dari sistem penyelenggaraan pemerintahan sehingga Desa memiliki kewenangan untuk mengatur dan mengurus kepentingan masyarakatnya (Penjelasan, Umum, angka 9, butir 2). Kepala Desa bertanggungjawab pada Badan Perwakilan Desa dan menyampaikan laporan pelaksanaan tugas itu kepada Bupati (Pasal 102).

Desa dapat melakukan perbuatan hukum, baik hukum publik maupun hukum perdata, memiliki kekayaan, harta benda, dan bangunan serta dapat dituntut dan menuntut di pengadilan. Untuk itu, Kepala Desa mempunyai wewenang untuk melakukan perbuatan hukum dan mengadakan perjanjian yang saling menguntungkan (Penjelasan, Umum, angka 9, butir 3).

Sebagai perwujudan demokrasi, di. Desa dibentuk Badan Perwakilan Desa atau sebutan lain yang sesuai dengan budaya yang berkembang di Desa yang bersangkutan, yang berfungsi sebagai lembaga legislasi dan pengawasan dalam hal pelaksanaan Peraturan Desa, Anggaran Pendapatan dan Belanja Desa, dan Keputusan Kepala Desa (Pasal 104 \& 105, lihat juga Penjelasan, Umum, angka 9, butir 4).

Di Desa dibentuk lembaga kemasyarakatan Desa lainnya sesuai dengan kebutuhan Desa. Lembaga dimaksud merupakan mitra Pemerintahan Desa dalam rangka pemberdayaan masyarakat Desa (Pasal 106, lihat juga Penjelasan, Umum, angka 9 , butir 5 ).

Desa memiliki sumber pembiayaan berupa pendapatan Desa, bantuan Pemerintah dan Pemerintah Daerah, pendapatan lain-lain yang sah, sumbangan pihak ketiga dan pinjaman Desa (Pasal 107 \& 108, lihat juga Penjelasan, Umum, angka 9, butir 6).

Berdasarkan hak asal-usul Desa yang bersangkutan, Kepala Desa mempunyai wewenang untuk mendamaikan perkara/ sengketa dari para warganya (Penjelasan, Umum, angka 9, butir 7).

\section{Kritik terhadap pengaturan desa dalam UU No. $22 / 99$}

Betapapun, melalui UU 22/99, ada langkah maju yang telah ditempuh Pemerintahan $\mathrm{Rl}$ untuk memulihkan akibat-akibat dari pemberlakukan peruturan-perundangan tentang desa selama ini. Seperti telah disebutkan dalam bagian terdahulu, melaluj pemberiakuan UU No. 22/1999 hasil reformasi ini telah mengembalikan kembali status desa kembali sebagai 'kesatuan masyarakat hukum'. Terlebih lagi, sebagaimana amanat Pasal 18 UUD 1945, otonomi asli desa diakui keberadaannya. Hanya saja, dengan pengaturan-pengaturan yang lebih lanjut tentang desa ini pengakuan yang dapat dikatakan mulia itu ternodai.

Pertama, di dalam batang tubuh UU No. 22/1999 Desa belum/tidak dinyatakan secara ekplisit memiliki otonomi. Penyebutan desa memiliki otonomi asli berada dalam bagian penjelasan (lihat Bagian Umum, Angka 9, Butir 1). Hal ini tentu terhitung lumayan dari pada tidak ada sama sekali. Namun akan menjadi lebih baik jika pengakuan itu berada dalam batang tubuh peraturan perundangan yang bersangkutan.

Dengan pengaturan-pengaturan lebih lanjut tentang desa, utamanya yang menyangkut keberadaan Pemerintahan Desa, 
Pemerintah Desa, Badan Perwakilan Desa, dan 'lembaga lainnya yang dianggap perlu', pengakuan otonomi desa terlihat menjadi setengah hati, kalau tidak mau mengatakannya sekedar basa-basi. Ingin dikatakan bahwa keberadaan pasal-pasal 94 dan seterusnya justru 'memperkosa' pengakuan otonomi desa yang dengan tegas telah dinayatakan pada Bab 1, Ketentuan Umum, Pasal 1, butir o sebagaimana telah dikutipkan di atas.

Dengan begitu, dapat dikatakan bahwa UU No. 22/1999 baru mengatur masalah Pemerintahan (Nasional) oleh Pemerintahan Desa (yang dibentuk di dalam desa), khususnya oleh Kepala Desa dan Badan Perwakilan Desa. Jadi bukan penyelenggaraan Pemerintahan Nasional oleh desa itu sendiri, sebagaimana makna otonomi asli yang diakui keberadaannya itu. Karenanya, Pemerintahan Desa di desa merupakan subsistem dalam sistem Pemerintahan Nasional.

Keberadaan Pasal 94, yang mengatur 'di desa dibentuk Pemerintahan Desa dan lengkap dengan perangkatnya (Pasal 95) akan menghasilkan Kepala Desa sebagai pimpinan Pemerintah Desa dan BPD (Pasal 105 dan 106), yang akan 'bersaing' dengan 'pemimpin-pemimpin desa' dan 'lembagalembaga perwakilan asli', jika ada, di dalam desa yang bersangkutan.

Dengan demikian, tetap akan terjadi dualisme intitusi di dalam desa, masingmasing adalah Pemerintahan Desa dan desa itu sendiri, sebagaimana yang telah/ pernah terjadi pada masa-masa sebelum ini. Sebagaimana yang terjadi selama pemberlakukan UU No. 5/1979 yang ingin digantikan oleh UU No. 22/1999 ini, dualisme ini telah berdampak buruk. Sebab, sebagaimana yang terjadi selama ini, seluruh energi yang akan dialirkan ke dalam desa demi memajukan dan mensejahterakan kehidupan warga desa pastilah akan di- salurkan melalui Pemerintahan Desa. Pada saat yang sama, tanpa disengaja sekalipun, keberadaan desa yang sejatinya memiliki otonomi desa itu akan tersaingi.

Perlu kembali diingat, selama pemberlakukan UU No. 5/1979, pada dasarnya tidak pernah ada kebijakan resmi yang melarang kehadiran ataupun berfungsinya 'lembaga-lembaga sosial kemasyarakatan lainnya' termasuk desa (asli) sendiri. Dalam kenyataannya, karena seluruh energi yang dialirkan ke desa untuk memajukan masyarakat desa disalurkan melalui Pemerintahan Desa, keberadaan lembaga-lembaga sosial kemasyarakatan dan desa (asli) itu dengan sendirinya memudar. Situasi ini menjadi fatal sedemikian rupa karena, di satu pihak, lembaga desa baru tak dapat berfungsi sebagaimana mestinya, di pihak lain, desa lama kehilangan makna keberadaannya. ${ }^{31}$ Akibatnya, seperti yang ditunjukkan oleh sebuah hasil penelitian, ${ }^{32}$ pertama, institusi-institusi lokal (local level institution, seterusnya disingkat LLI) yang kuat kapasitasnya berada di tingkat atau lingkungan ketetanggaan saja. ${ }^{33}$ Akibatnya,

31Lebih lanjut lihat Zakaria, 2000, op.cit.

${ }^{32}$ Lihat Kamala Chandrakirana, Kamala. 1999. "Local Capacity and Its Implications for Development: The Case of Indonesia." World Bank/Bappenas, Local Level Institutions Study, Jakarta; Pieter J. Evers, 1999. "Village Governments and Their Communities." World Bank/Bappenas, Local Level Institutions Study. Jakarta; Christiaan Grootaert. 1999. "Social Capital, Household Welfare and Poverty in Indonesia." World Bank, Social Development Department, Washington, D.C.; Christiaan Grootaert. 1999. "Local Institutions and Service Delivery in Indonesia." World Bank, Social Development Department, Washington, D.C.

${ }^{3}$ Kapasitas intitusi (lokal) adalah terminologi yang digunakan untuk menandai 'kemampuan suatu komuniti dalam mengorganisasikan kegiatan bersama untuk memenuhi 
dengan demikian, pada dasarnya warga komunitas yang menjadi target group berbagai proyek pembangunan dan penanggulangan kemiskinan tidak mampu 'mempengaruhi' (baik dalam arti sebagai mitra, saingan, kontrol, dan sebagainya) proyek-proyek pembangunan dan penanggulangan kemiskinan yang pada hakekatnya - atas dasar kebijakan yang ada- diselenggarakan oleh pemerintah desa bersama-sama berbagai organisasiorganisasi mitra resminya, semisal LMD, LKMD, kelompok PKK, Karang Taruna, KUD, dan lain sebagainya. Kolaborasi cenderung terjadi diantara komunitaskomunitas dengan kelompok-kelompok sejenis, bukan dengan pemerintah. Delapan puluh persen hubungan dengan pihak luar komunitas adalah dengan kelompokkelompok non pemerintah. Akibatnya, seperti telah pula banyak diungkap, banyak proyek pembangunan dan panggulangan kemiskinan itu yang tidak sampai pada sasaran yang sebenarnya.

Kedua, secara umum, pemerintah Indonesia tidak berhasil bekerja dengan kapasitas yang tersedia untuk meningkatkan perencanaan dan implementasi proyekproyek dan layanan jasa. Pemerintah di tingkat desa lebih bersikap mewakili pemerintah di tingkat atasnya daripada bertindak sebagai wakil dari konstituennya di desa. Dengan demikian, pada hakekatnya pemerintah telah menghancurkan kapașitas lokal melalui pembatasan-pembatasan dalam melaksanakan proyekproyek dan tidak mendukung proyek-proyek yang diajukan masyarakat. Proses perencanaan dari bawah yang dilakukan pemerintah tidak responsif terhadap kebutuhan-kebutuhan lokal yang telah teridentifikasi dan tidak merangsang berkembangnya kapasitas pengorganisasian. Karena adanya pembatasan terhadap penyedia jasa dari pihak masyarakat, berbagai institusi yang ada pada komunitas, yang sebenarnya bisa ikut berperan dalam pengurangan kemiskinan dan pembangunan politik menjadi 'hilang'. Kesalahan manajemen dana-dana proyek dan kegagalan proyek-proyek inisiatif pemerintah menyebabkan kekecewaan terhadap kemampuan pemerintah dalam menyediakan layanan sosial. ${ }^{34}$

kebutuhan dan mengatasi masalah bersama' (Pieter J. Evers, "Resourceful Villagers, Powerless Communities: Rural Village Government in Indonesian, Working Draft Local Level Institution Study/lndonesia, a Word Bank/ Bappenas Research Project, January 2000, hal. 2). Uphoff (1997, op.cit., hal. 9), mengatakan bahwa 'the capacity of any organization, whether also as institution or not, depends on the successful performance of these (decision-making, wich includes planning and evaluation; resource mobilizaion and management; communication and coordination; and conflic resolution) task. If they are not perform, at least to some degree, one cannot say that an organization exist, no matter what formal claims are made to the contrary. This is not all there is to organization, but these activities are essential. Where these task are performed more eften, more fully, more predictably and more effectively, we can say that there is greater organizational capacity, and more potential for institutionalization from affectiveness'.

${ }^{34}$ Pengecualian terdapat dalam kasuskasus dimana kepala desa yang proaktif (ditemukan di kurang dari sepertiga komunitas yang diteliti) bisa memfasilitasi hubungan antara pemerintah dan pemuka masyarakat dan menjadi mediator konflik. Dalam kasus dimana kepala desa tidak kooperatif, pilihannya hanyalah memutuskan hubungan (lebih dari separuh kelompok komunitas yang aktif tidak melibatkan kepala desa dalam kegiatan mereka). Komunitas dengan kapasitas organisasi yang paling rendah juga mempunyai pemerintahan desa yang paling buruk. 
Pelajaran ketiga, studi LLI (1) menunjukkan pula, meski baru secara samarsamar dan tidak lengkap, bahwa sebenarnya ada institusi-institusi maupun organisasi-organisasi lokal lain yang memiliki daya jangkau dan daya dukung yang lebih luas, sehingga, secara hipotetis, masingmasing institusi dan organisasi itu sanggup menjadi modal sosial bagi, baik sebagai mitra maupun 'penyeimbang' pelaksanaan proyek pembangunan, maupun sebagai pelaksana proyek-proyek pembangunan itu sendiri. Institusi-instusi dan organisasioranisasi dimaksud berupa institusi-institsi dan organisasi-organisasi yang terbentuk atas dasar nilai-nilai ajaran agama, sistem kekerabatan, sistem (hukum) adat, sistem organisasi pemerintahan tradisional, dan lain sebagainya. Hanya saja, memang, kapasitas masing-masing institusi dan organisasi itu dalam kondisi yang terus menurun daya dukungnya. Baik karena adanya upaya-upaya yang sistematis (baca: sengaja) dan secara langsung melemahkannya, maupun karena akibat proses-proses yang alamiah, sebagai dampak dari perubahan-perubahan yang terjadi baik di lingkungan dalam maupun lingkungan luar institusi dan organisasi tradisional itu sendiri. Melemahnya kapasitas institusi dan organisasi-organisasi tradisional dimaksud seringkali terjadi karena memang tidak diberikannya ruang partisipasi yang berarti, yang pada akhirnya memungkinkan institusi-institusi dan organisasi-organisasi itu berkembang sesuai dengan tuntutan zamannya. ${ }^{35}$

Pengaturan tentang Pemerintahan Desa di desa sebagaimana yang ada dalam UU No. 22/1999, yang tidak secara eksplisit menyatakannya sebagai suatu unit yang otonom, dan lebih menyibukkan diri dengan hal-hal teknis seputar kedudukan dan peran Kepala Desa, BPD, dan perangkat Pemerintahan Desa lainnya, dengan sendirinya mengaburkan makna pengakuan desa sebagai kesatuan masyarakat hokum. Karenanya, perubahan yang terjadi itu dapat dikatakan 'setengah hati'.

Implikasi langsungnya adalah perubahan ini dengan sendirinya tidak menyelesaikan konflik tenurial di desa, yang menjadi salah satu dasar bagi ketegangan antara negara - desa (komuniti) selama ini. Hak tenurial ini, atau yang kemudian disebut hak ulayat itu, melekat pada badan hukum yang disebut desa itu sendiri. Karena itu pula desa dapat disebut sebagai 'kesatuan masyarakat hukum' yang sekarang sudah tercantum/diakui kembali dalam UU No. 22/1999.

Sebab itu, yang dibutuhkan adalah pengembalian otonomi desa seutuhnya (termasuk haknya sebagai subjek hukum dari hak ulayat dimaksud); pengakuan desa sebagai badan yang menerima kewenangan penyelenggaraan Pemerintahan Nasional hanyalah salah satu saja dari sekian kebutuhan yang harus dipenuhi dalam otonomi penuh tersebut.

Hanya dengan cara demikianlah ketegangan antara negara - desa dapat diselesaikan. Dengan cara demikian pula dualisme yang terjadi di desa selama ini, dan yang telah merugikan warga desa, dapat diselesaikan/dihilangkan. Dengan pemberian otonomi penuh itulah akan tercipta komuniti yang sehat dan hidup, yang dibutuhkan bagi kelangsungan keberadaan Negara ini di masa-masa yang akan datang.

${ }^{35}$ Lihat juga Zakaria, 2000, op.cit. 


\section{Lima Kebutuhan Mendesak bagi Pemulihan Kehidupan di Desa}

Hemat saya, untuk dapat menyusun kebijakan ataupun perangkat peraturanperundangan untuk memulihkan kehidupan di desa ataupun bahkan meningkatkan kesejahteraan di desa, terlebih dahulu harus diperiksa apa sebenamya kebutuhan menuiur 'orang desa' itu sendiri. Pengalaman saya dan beberapa teman lainnya, katakanlah sekitar belasan kali, memfasilitasi berbagai pertemuan konsultasi ataupun musyawarah di tingkat kampung maupun dengan berbagai kelompok aktivis ataupun 'pendamping masyarakat' di tingkat lapangan menunjukkan adanya kesamaan kebutuhan ini. Dalam berbagai kesempatan itu kami coba melontarkan sebuah pertanyaan yang bersifat umum, yakni: tolong diskusikan empat hingga lima kebutuhan masyarakat agar lima hingga sepuluh tahun mendatang kehidupannya tetap bisa seperti sekarang atau malah lebih baik dari masa sekarang ini'.

Melalui diskusi kelompok, jawaban yang muncul atas pertanyaan umum yang demikian adalah sebagai berikut: ${ }^{36}$

Kelompok A:

- Ketersediaan SDM dan SDA yang memadai

- Sistem kepemimpinan dimana pemimpin formal dan nonformal bekerjasama

- Partisipasi dari semua komponen yang membentuk kehidupan bersama

- (masih kosong, belum sempat didiskusikan)

Kelompok B:

- Kesadaran dari desa dan luar desa untuk mengubah situasi

- Kesadaran dari semua unsur untuk bekerja sama

- Aturan yang melemahkan desa harus diubah

- Menghidupkan demokrasi yang sesungguhnya

Kelompok C:

- Adanya institusi rakyat/kelembagaan lokal yang dapat mengakomodir kepentingan masyarakat

- Ketahanan ekonomi, sarana dan prasarana (misalnya jalan)

- Situasi yang menjamin keselamatan hidup (faktor alam dan kebijakan)

- Ketersediaan SDA yang memadai didukung dengan pelestarian alam

- Pelibatan /partisipasi masyarakat yang tinggi (campur-tangan pihak luar dikurangi, kalaupun ada hanya sebagai pendorong)

\section{Kelompok D:}

- Pengakuan terhadap institusi lokal

- Kebebasan untuk mengekspresikan diri

- Adanya akses masyarakat terhadap proses pembangunan

- Dibubarkannya partai politik

${ }^{36}$ Contoh berikut dicuplik dari 'Lokakarya Konsultasi dan Pendalaman Hasil Penelitian LLI 2', di Desa Rakateda, Kecamatan Mangu- 
Melalui proses diskusi di tingkat pleno, keenambelas kebutuhan yang keluar dari hasil diskusi kelompok sepakat untuk disarikan menjadi 5 (lima) kebutuhan yang dianggap mendesak, agar masyarakat yang bersangkutan dapat hidup sama atau bahkan lebih baik pada 5 sampai 10 tahun mendatang. Masing-masing adalah sebagai berikut:

1. Terjaminnya persediaan dan penguasaan sumber-sumber kehidupan, terutama tanah;

2. Terjaminnya sistem produksi masyarakat;

3. Adanya kesempatan untuk mengatur kehidupan bersama sesuai dengan nilainilai, norma, dan aturan-aturan yang dipahami oleh masyarakat

4. Terbukanya kesempatan sistem reproduksi sosial yang memungkinkan terciptanya nilai-nilai, norma, aturan-aturan, kecerdasan baru yang dibutuhkan bagi keberlangsungan hidup, sesuai dengan pengetahuan, norma dan nilai, dan hukum yang dikenal masyarakat;

5. Adanya upaya untuk memperluas partisipasi politik rakyat demi perubahan struktur politik yang ada.

Adapun beberapa argumentasi yang sempat dilontarkan mengapa muncul 5 kebutuhan mendesak di atas, dan yang perlu dikemukakan dalam kesempatan ini adalah, antara lain, (a) Kita membutuhkan peraturan yang menguatkan penguasaan tanah kita, karena jika tidak suatu saat tanah kita bisa hilang, karena tidak diakui, jadi bisa saja tanah kita diambil oleh proyek atas ijin negara; (b) Misalnya retribusi oleh Pemda. Pedagang harus membayar retribusi, sehingga pedagang menekan harga komoditi rakyat agar dapat membayar retribusi dengan tetap mendapatkan keuntungan; (c) Kesempatan mengatur kehidupan bersama dimungkinkan oleh $U U$ No. 22. Misalnya nama BPD juga dapat diganti dengan yang lain. Di Minangkabau, BPD disebut dengan KAN. Dengan nama ini orang Minang sudah tahu akan hak dan kewajibannya sebagai KAN, sehingga tidak perlu disosialisasikan lagi yang menghabiskan biaya; (d) Sistem reproduksi sosial misalnya sistem pendidikan; agama; hukum adat dan sebagainya; (e) Sebenarnya posisi adat kita sekarang macet, kita berpegang pada nilai lama yang diciptakan oleh nenek moyang kita yang tentunya untuk menyelesaikan masalah pada masa lalu. Untuk itu perlu pembanuan-pembanuan pada adat juga; (f) Kebutuhan 1-4 dapat diperjuangkan melalui pembaruan kebijakan; (g) sedangkan kebutuhan no.5 tergantung pada dari kita sendiri, apakah bisa melepaskan diri dari kungkungan janjijanji partai politik yang ada.

Demikianlah, seperti telah dijelaskan daam bagian terdahulu, hak asal-usul melekat kepada empat hal tersebut pertama. Jika hak asal-usul pada keempat hal tersebut terjamin keberlangsungannya barulah kita dapat mengatakan adanya otonomi desa itu.

lewa, Kabupaten Ngada, Flores, NTT, yang berlangsung pada tgl. $18-23$ Februari 2002 yang lalu. 


\section{Tawaran Bagi Pemulihan Kehidupan Desa}

Berangkat dari kebutuhan orang kampung sebagaimana telah dicontohkan di atas, melalui pengakuan terhadap hak asal-usul, maka yang diperlukan adalah Undang-undang dan/atau Peraturan Daerah yang mengatur tentang Penyelenggaraan Pemerintahan Nasional di Desa (atau disebut dengan nama lain) dalam Wilayah Administrasi Negara Rl dan/atau pada Daerah Kabupaten/Kota.

Setidaknya Undang-undang dan/atau Peraturan Daerah dimaksud mengatur halhal pokok berikut:

- Pernyataan-pernyataan dan/atau ketentuan-ketentuan tentang adanya 'otonomi' pada 'susunan-susunan asli' sebagaimana dimaksudkan oleh UUD 1945 Pasal 18 (seperti desa, nagari, marga, dan lain-lain yang kesemuanya dicetak miring yang berbeda dengan desa cetak biasa);

- Pernyataan-pernyataan dan/atau ketentuan-ketentuan tentang definisi Desa di wilayah dimaksud; berikut dengan mekanisme-mekanisme pengembangannya;

- Pernyataan-pernyataan dan/atau ketentuan-ketentuan tentang Desa di wilayah dimaksud sebagai penyelenggara Pemerintahan Nasional di wilayah Desa dimaksud (dalam hal Perda adalah sebagaimana diatur dalam UU No. 22/99, bagian Ketentuan Umum, butir o.). Dengan cara ini maka dualisme institusi di desa tidak terjadi. Desa adalah (system) Pemerintahan Desa itu sendiri. Penyelenggaraan pemerintahan Nasional di tingkat desa, dengan demikian, hanyalah merupakan salah satu tugas dari institusi/organisasi desa itu sendiri.

- Pemyataan-pemyataan atau ketentuanketentuan tentang corak hubungan Desa dengan unit-unit Pemerintahan
Nasional yang lainnya, seperti kecamatan, kabupaten dan propinsi;

- Pemyataan-pernyataan atau ketentuanketentuan tentang aturan-aturan peralihan. Dalam bagian ini penting untuk ditegaskan adanya perintah pada Negara, entah nasional ataupun Daerah, untuk mengalokasikan dana negara bagi upaya-upaya perbaikan kenusakankerusakan sosial dan ekologasi sebagai akibat kekeliruan penerapan kebijakan sebelumnya, dan juga untuk memantapkan pilihan-pilihan bentuk pemerintahan desa yang akan ditempuh pada masa-masa yang akan datang;

- Agar Perda 'Pemerintahan Desa' yang sesuai dengan 'adat setempat' ini memiliki cantolan hukum yang lebih kuat (UU No. 22/1999 hanya UU tentang Pemerintahan Daerah karenanya sulit menerapkan otonomi asli sepenuhnya) maka, ditingkat Nasional, diperlukan pula UU tentang pengakuan 'hak asal-usul susunan asli, atau komuniti, atau masyarakat adat' itu sendiri; ${ }^{37}$

- Terakhir, yang lebih pokok adalah, mengingat kebijakan-kebijakan lama, ataupun perkembangan sosial, ekonomi, politik dan budaya lainnya, telah merubah kehidupan di desa, Perda dimaksud juga membuka peluang bagi terakomodasinya keberagaman desa di

${ }^{37}$ Sejauh yang dapat saya ikuti, rasanya kritik dan tawaran rancangan UU dari Forum Pengembangan Partisipasi Masyarakat-lah yang mendekati konsepsi yang saya kemukakan di atas (Lihat Forum Pengembangan Partisipasi Masyarakat, Usulan Naskah Akademik Tentang Perubahan UndangUndang Republik Indonesia Nomor 22 Tahun 1999 yang Berkaitan dengan Desa. Jakarta, Agustus 2001. Hanya saja, hemat saya, dalam beberapa hal, usulan tersebut masih juga terjebak untuk mengatur, dan dapat berakibat melemahkan, pengakuan otonomi desa. Ambil 
daerah yang bersangkutan; termasuk terakomodasinya keberagaman pilihan bentuk 'pemerintahan desa' yang sesuai dengan aspirasi konstituennya, apakah akan dilaksanakan secara 'adat' atau 'secara formal', seperti yang terjadi -dan berdampak baik bagi kehidupan masyarakat di daerah yang bersangkutan - di negara bagian Oaxaca. Mexico). ${ }^{38}$ Dalam situasi yang telah berubah itu ada baiknya juga jika komunitas diberi kesempatan untuk memilih sistem 'pemerintahan desa' yang paling cocok bagi kehidupan masyarakat itu pada hari ini. Pilihan itu bisa saja menyangkut tetap menjalankan sistem 'pemerintahan formal' ataupun kembali secara adat yang pernah dikenal sebelumnya. Adanya ruang pilihan ini pada hakekatnya merupakan ekspresi dari pengakuan atas adanya keberagaman di tingkat komunitas itu sendiri. Sebuah kebijakan baru yang tidak membuka kemungkinan ini sama saja dengan memindahkan penyakit sentralisasi yang semula di tingkat nasional menjadi sentralisasi di tingkat lokal (daerah).

\section{Penutup}

Saya percaya bahwa keberlangsungan Negara ini juga akan ditentukan oleh seberapa jauh Negara ini mampu menata ulang hubungannya dengan desa. Tidak akan ada Negara yang akan bertahan - tanpa tindakan-tindakan politik yang represifjika tidak didukung oleh komuniti yang sehat dan hidup. Sementara itu, tindakantindakan politik yang represif hanya akan mengantar Negara itu pada posisi 'sementara' dan 'tidak mantap'. Begitu pula, masyarakat sipil sejati tidak akan tercipta tanpa kehadiran komuniti-komuniti yang sehat dan hidup itu.
Sejatinya Negara memang harus selalu dalam posisi 'sementara' dan 'tidak mantap', karena, seperti dikatakan Anderson, Negara adalah 'sesuatu kesatuan masyarakat yang dibayangkan ada'. ${ }^{39}$ Hanya saja, core kehadiran Negara itu harus dirubah dari yang berpusat pada Negara itu sendiri kepada komuniti. Dengan meletakkan core kehadiran Negara pada komuniti sekaligus akan menghindarkan kita dari makna sakral Negara -yang dalam sejarahnya- bersimbah darah itu. Dengan posisi yang demikian itu maka Negara tak lebih sebagai suatu sistem administrasi kehidupan bersama yang lentur, adaptif, sama sekali

contoh tentang bagian 'Pokok-pokok Materi Muatan yang akan Diatur', d), d.1. dan d.2. Hemat saya, pengakuan atas otonomi desa tidak mesti bermuara pada pembentukan Pemerintahan Desa tapi cukup ada bagian yang mengurusi masalah 'pemerintahan nasional' di desa yang otonom itu. Dalam banyak kasus yang lain, termasuk prosesproses yang mendapat intervensi dari kalangan ornop, peluang perbaikan yang ada hanya bermuara pada sekedar 'mengganti nama desa' dengan 'nama yang cocok di derah yang bersangkutan'.' Bahkan dalam perdaperda tentang Nagari di Sumatera Barat, perda ttg. Lembang di Tana Toraja, dan perda tentang Kampung di Sanggau, Kalbar, yang difasilitasi melalui proses-proses pertemuan di tingkat kampung sekalipun. Hal yang demikian terjadi, hemat saya, terutama terletak pada kelemahan atau belum clear-nya pengertaian tentang otonomi desa itu sendiri.

${ }^{38}$ Sekedar menyebut satu dokumentasi, periksalah Noer Fauzi, et.al., Trampas Muchas Politicas: Catatan Perjalanan ke Meksiko. Jakarta: Ford Foundation, Tahun 2000. Tidak diterbitkan.

${ }^{39}$ Benedict Anderson, KomunitasKomunitas Imajener, Renungan Tentang AsalUsul dan Penyebaran Nasionalisme. Yogyakarta: Pustaka Pelajar dan INSIST Press, 1999. 
tidak sakral, sehingga tidak perlu ditangisi, apalagi berkorban nyawa, jika ia memang harus berubah areal cakupan, sesuai tuntut-. an zamannya.

Saya juga telah menunjukkan bahwa sama sekali tidak ada alasan yang kuat untuk menguatiskan pemberian otonomi penuh ini kepada komuniti. Sebaliknya, saya malah telah pula menunjukkan bahwa pengingkaran terhadap hak-hak otonomi komuniti inilah yang justru menjadi kayu bakar bagi gerakan-gerakan yang mengarah pada disintegrasi Nasional..$^{40}$
Yang ingin dikatakan adalah, entitas suatu Negara hanya relevan dalam satu jangka waktu tertentu saja. la bisa mengkhianati rasa keadilan komuniti, dan bahkan bisa saja menindas peri kemanusiaan, dalam konteks waktu yang lainnya. Karenanya, Negara, terlebih lagi negara-bangsa, sebagai sesuatu yang diimajikan (akan) ada itu, haruslah diletakkan sebagai satu sasaran antara, bersifat sementara, tidak mantap, dan sama sekali tidak sakral. Hanya dengan begitu kita dapat lepas dari paradoks-paradoks kehadiran Negara dan 'sesat pikir' tentang (konsep) Negara itu sendiri.
${ }^{40}$ Tentang hal ini kembali periksa Zakaria, op.cit., 2000. 